\title{
Analysis of Criminal Responsibility of Users of Chemical Weapons in International Documents
}

\author{
Mahmud Buolagh $^{1} \&$ Habib Zuori ${ }^{2}$ \\ ${ }^{1}$ Assistant Professor of Criminal Law and Criminology, Islamic Azad University of Zahedan, Iran \\ ${ }^{2}$ Masters Student of Criminal Law and Criminology, Islamic Azad University of Zahedan, Iran \\ Correspondence: Mahmud Buolagh, Assistant Professor of Criminal Law and Criminology, Islamic Azad \\ University of Zahedan, Iran. E-mail: esfehani.mohamad3@gmail.com
}

Received: December 27, 2016

Accepted: January 18, 2016

Online Published: February 1, 2017

doi:10.5539/mas.v11n2p87

URL: http://dx.doi.org/10.5539/mas.v11n2p87

\begin{abstract}
The article is written entitled "Analysis of criminal responsibility of the users of chemical weapons". The issue of chemical weapons and criminal responsibility of users of this weapon is very important because countries like Iran starting a war of aggression and invasion against violations of humanitarian law, international criminal is not considered responsibility for the instigators of war. This study aimed to explore international responsibility of individuals and legal assign and use of chemical weapons and the role of domestic law in support of victims of such weapons has been developed. The main hypothesis of this study tries to answer this question that what challenges are dominant criminal responsibilities of users of chemical weapons. It states that; the impact of global powers on international issues are the lack of law, guarantees, good performances and the most important challenges is the lack of cooperation by governments. This research, descriptive analysis of documents, according to primary sources, including data and legal jurisprudence and secondary sources, including laws papers has been developed. The findings of this study show that, the principles of international law banning the use of chemical weapons, in addition to the contract law, is customary international law, hence, even if the country has no weapons of mass destruction also a member of the international conventions, proscription, in case of violations of international humanitarian law can still be prosecuted in the s.
\end{abstract}

Keywords: chemical weapons, organizations and international documents, jus cogent norms, international law, international responsibility

\section{Problem Statement}

More than a century that terrible image and the results of its chemical weapons warning has been repeated many times by the bill and regulations that the purpose of deployment is destruction large groups of human.

Weapons of mass destruction in the world today debates, that no category can be easily ignored so that international reactions against this is very severe, including a discussion of Iran's use of nuclear science and international pressure, but it is not reasonable to Iran's efforts to acquire nuclear technology so much pressure on the international level can be charged; while no country like Iran in recent centuries, have been a victim of weapons of mass destruction.

Authors, discussed case studies on Criminal Responsibility of users of chemical weapons in international documents with the aim of explaining the positions of international organizations on the use of chemical weapons with the approach to Jus cogens norms rules and sanctions violate the rules. Suffice to say that today's research on the necessity of the principle of the prohibition of the use of force, the Jus cogens norms of international law and the rule of international law. The main question of this study is that what use of chemical weapons challenges the ruling of criminal responsibility. Therefore, we raised the hypothesis states that; the impact of global powers on international issues, lack of law guarantees good performances of the most important challenges is the lack of cooperation by governments; hence this study is descriptive-analytic.

\section{The Criminal Liability of Legal Persons Against Using Chemical Weapons}

The globalization of criminal law, as accepting the rules of criminal law at the international level through international legal processes, with the establishment of the International Criminal has reached a tipping point. This coordination of domestic law on international crimes from the perspective of an international obligation and 
domestic legal political expediency can be evaluated. Meanwhile, the "principle of the prohibition of the use of force or threat to use it" in modern international law was universally accepted (Paragraph 4 of Article 2 of the UN Charter) and states as one of the basic principles of the UN Charter in the document that "the supreme international obligations", manifested (Article 103 of the Charter), but the development and codification of international law of armed conflict or law of war continues. In other words, with the outbreak of the war, has been prohibited, but ignored the reality of war and the rules for how the war is being developed. On the other hand, rapid advances in military technology, endless power granted to the warmongers that may this power, scarify human life and their humanitarian feelings to selfish power-seeking them out. It also stressed the need to regularize the reality of war has increased. Inefficiency "of the prevention of war," especially in practice proven and "prohibition of War" has not led to "the rest of the war". (King, 2006, p. 178)

Therefore, the development of international law of war requires consideration of the guarantees for its implementation. Today, the law of war has an extensive system of enforcement that is the primary objective to support the victims, not punishing the offender. In this way, war crimes, crimes were the first who were prosecuted under international law and was trying to treat these crimes as crimes that ignore common values of human society (Shibs, 2005, p. 56).

It should also be noted that in most cases with impunity of perpetrators of war crimes have been under international law and in the context of their country for the sake of rule by dictatorship, saw no need to answer their actions. The examples of such rulers are "Milosevic" in the former Yugoslavia, "Pinochet" in Chile and "Saddam Hussein" in Iraq, which all three died in 2006. Among them was only Saddam Hussein's trial and judicial condemnation "in the name of justice" was executed, and the other two died naturally. No doubt the will of big powers and the UN Security Council in the prosecution or non-prosecution of such criminals can be more effective. Because volition will power supporters of peace, justice, human rights and the establishment of an independent and impartial tribunal to prosecute these criminals emphasized the political process and today the formation of the International Criminal , mere existence of the tribunal, the government committed to the pursuit and punishment of crimes including war crimes, "the territories" or "by their nationals" will be examined because otherwise, would be likely to interfere (Zamani, 2002, p. 78 ) therefore, many countries in compliance with international standards and the standardization of criminal law to prosecute these crimes on their territory.

\subsection{The Government's Commitment under the Treaty Banning Chemical Weapons}

Major governments' commitments include the following:

1. The lack of production, development, acquisition, storage nuclear and the lack of transfer them, destruction of chemical weapons and their related facilities;

2. Non-transfer of chemical weapons and the technology to produce such weapons;

3. Banning the use of chemical weapons;

4. Full information regarding the inventory of chemical weapons "materials used in them", related chemical weapons production facilities and their location, type of chemicals in the country, measures related to weapons destruction facilities and the grant application.

In addition, all governments are equal in rights and obligations.

\subsubsection{Measures International Atomic Energy Agency to the Governments Abuse}

Due to the intensity and type of violations committed by governments' restrictive measures that provided for in the articles of association are:

\section{Suspension of voting rights}

In the event of non-payment of dues and financial obligations of the member states, they will be deprived of the right to vote in the organs of the agency. Suspension of voting rights prevents companies' member states in preliminary negotiations and meetings and do not recommended.

\section{Suspension Points}

If a member persistently violates the provisions of the statute or the agreement statute and these violations, ignored the ultimate goals of the treaty, if the board of governors' general conference of member states has requested suspension and the proposal is approved by the conference, a state party to the rights and privileges will be suspended.

\section{Suspension of ratings and reports to the UN Security Council}

If a non-nuclear member states, violate the main goals of nuclear non-proliferation treaty and facilities and 
nuclear material for weapons or other explosive devices in his possession to apply nuclear or in violation of a 2 of the treaty, nuclear weapons, or conventional measures that IAEA inspectors could not verify the government's commitment, or the government for a fraction of these nuclear materials, does not provide acceptable reasons, or does not agree to allowing an immediate inspection of nuclear facilities and sites requested by the agency, the suspension of membership rights and privileges of a member state, the assistance provided by the Agency may also be returned to them and far infringement by the board to the general assembly of the United Nations Security Council, the general conference of the state's parties shall be declared (Yadegarfar, 1977, p. 133).

\subsubsection{Measures Organization for the Prohibition of Chemical Weapons Offenses Against Governments}

\section{Suspension of voting rights}

If any of the members refuse to pay their dues, so that the amount of debt the state is equal to or greater than the quota two years will be deprived of the right to vote in the organs.

Limitation and suspension of rights and privileges

In cases where member states violate part of its commitment to this cause, in compliance with the state or states Parties to the treaty concerns or doubts, executive council member of the government or governments that ignored the legal rights, enter into discussions, and to prove their commitment to determine the reasonable amount of time. State or member states during this period should have common corrective actions requested by the executive council. Otherwise the executive council of state or government of the member states of abuse situated a member of the conference of states parties will take the matter to the notice. If this is unsuccessful the offending government or governments continue to violate the regulations, recommends to the general conference the limitation or suspension of the rights and privileges. If two-thirds of the members present, at the request of the executive council vote, rights and privileges of the offending state or government, will limit or suspend. Collective actions and report back to the UN Security council for collective action against the offending member state, the most severe preventive measure is the organization for the prohibition of chemical weapons whereby treaty provisions will apply. To implement such measures, violations must also be severe and corrupt the higher goals of the Treaty. (Yadegarfar, 1977, pp. 135-134)

\subsection{Analysis on the Criminal Responsibility of Legal Entities}

Responsibility of legal entities in general and criminal responsibility in particular in domestic law and international law has been a history of ups and downs and still is controversial and widely contested issue. Always by lawyers, there are several objections to the criminal liability of legal persons and especially the government, including that: First, the attribution of criminal action to legal entities is not possible because it is caused by the fault of criminal responsibility and one can be guilty of criminal negligence that has no intention of independent legal entity.

Secondly accept criminal liability for legal entities, contrary to the principle of personal punishment, because when we apply penalties against legal persons, in fact, punishment is applied against its constituent members who are not involved in crime.

Thirdly, if we consider the nature of criminal penalties, we see that this punishment has been chosen so that fits natural persons (real), For example, a legal person cannot be executed or imprisoned. (Afrasyabi, 1977, p. 35).

Today, in America has been accepted criminal responsibility of legal persons. Corporations, political groups, and professional organizations for illegal activities in the name and on behalf of the legal person have been held accountable for their criminal terms. The new French Criminal Code (article 191-2) was approved by the legislature in 1992 criminal responsibility of legal persons for the first time explicitly and in spite of legal theory and jurisprudence and the former legal texts were adopted (Solomon, 1976, p. 205).

Iranian criminal law, under article 143 of the IPC in 2013 as a general principle of criminal responsibility of legal persons was accepted of course, only the criminal responsibility of individuals (administrators and directors) is accepted.

\subsubsection{Expression of Criminal Responsibility of States}

The concept of criminal responsibility of governments after world war I began, in the twenty-first century has entered a new phase. Uncertainty and constitute a or international reference for tackling the crime of governments, complexity and lack of definition of the crime of government and legal evidence that this concept is defined at the international level, has always attracted the minds of philosophers and lawyers. In this article it is tried to investigate the history of the concept and history of legal developments and current trends in the contemporary world some fundamental questions raised in this regard, and in response, too poor to be found for 
them. The most important of these questions include: what is the content of the concept of state crime and international crime of government? What rules will define the international order?

Since no statute, the criminal responsibility at the international level, there are no approved temporary or permanent international tribunal for investigation of criminal responsibility of government so far the s have been formed and have individual criminal responsibility, the theoretical aspects of the issue is a guide to act based on past experience. Therefore it is practical examples of international $\mathrm{s}$ and tribunals have been established so far or decisions regarding offenses committed at the international level in the continued international adoption will be discussed.

Notes that the main offenses under the jurisdiction of the International criminal, on the basis of the Statute, currently are included: Genocide, crimes against humanity, war crimes and crimes of aggression. Statute of the, on the seventeenth of July 1998, at the headquarters of the UN food and agriculture organization in Rome, signed by 120 countries out of 160 countries were participating in the Rome diplomatic conference and more than 60 countries to its accession (on 11 April 2002 pursuant to Article 126 of the constitution of July 2002) entered into force. 1919 peace treaty known as the treaty of Versailles that moreover ended the war, created the league of nations, article 277 itself, one of the first international criminal forecast responsibility of the head of the governments.

After World War II this question raised if a state has in addition to the political responsibility and individual criminal responsibility too?

Allies intend to hold on prosecuting the war criminals were brought up during World War II and shortly after the unconditional surrender of Germany in the eighth My1945, were also mentioned in Potsdam agreement. Since the end of World War two fronts, one in Europe and one in the far East was under way, two separate was established to prosecute war criminals in Nuremberg and Tokyo. (Mirmohammadsadeghi, 1997, pp. 37-36).

The first meeting of the international military tribunal in Nuremberg on 18 October 1954 in Berlin and was established under the chairmanship of a member of the Swiss General Nyket Chenko. Indictment against 24 former Nazi leaders was charged and six groups or organizations that are criminal in nature, was issued. In this as the guilty were four organizations that included the Nazi Party, SS, SD and Gestapo. (Solimi, 1976, p. 210).

After World War II military, was never accepted criminal responsibility of entities persons. In the annual report of the International Law Commission on the law of crimes against peace and human security, has stated that only real individuals have criminal responsibility. And commission even in its final plan completed in 1996, in article 2 stipulates that only individuals have criminal responsibility. In the twentieth century many of the practices that violate human rights treaty or cause harm to human dignity to provide, or a threat to international peace and security, has been concluded. For example, the ICRC treaties four August 12, 1949 and June 8, 1977, all subsequent protocols on human rights are published. And the Geneva conventions, which are major, sources of international criminal law. The draft law offenses (crimes) against peace and human security and in accordance with paragraph 1 of article 3 of the responsibility and punishment of any person who has committed a crime against peace and human security, it is responsible and punishable.

In the draft articles on responsibility of states, ILC on the basis of international responsibility, its material scope and content, forms and degrees of international responsibility, has predicted. This article shows that, in practice, lead to the responsibility of governments is, the following: the policy of apartheid in South Africa, the ship warrior rainbow ninth July 1985, Lockerbie twenty-one December of 1988, the war in Iraq and Kuwait in 1990 (Rahgosha, 2007, pp. 8 -7)

\subsubsection{Evolution Criminal Responsibility of States on the Eve of the Twenty-First Century}

Legal lawsuit against the government in the International of Justice (ICJ)

International of Justice under Article 92 of the Charter of the principal organs of the United Nations, in 1946, was formally replaced the permanent of International Justice. International of justice statute, procedures and practices relating to claims, proceedings and action to the decision or advisory opinion. International of Justice has two adversarial and advisory competences. Adversarial jurisdiction relates to the hostility and substantive decision on the case to which the has been proposed and competence to request an advisory opinion that the advisory is relevant security council and general assembly of the United Nations both in all cases, as well as some of the pillars and the specialized agencies - in activities range - the 's request. Under paragraph 1 of article 35 of the statute, states that signed the articles of association, the right to have the action. But it must be considered that paragraph 1 of article 93 of the UN charter also states: All members of the United Nations itself statute of the $\mathrm{C}$ of adopters, so all UN member states in case of a dispute with another State can - under 
appropriate conditions - refer to the tribunal. (Mir Abbasi, 1982, p. 158) Under the statute, only the states that can be appear in the as calling or accused. However, a State may exercise diplomatic protection to its nationals in case the small, provided that before filing lawsuits, is passed read all internal procedures with the government's compensation claim.

\subsubsection{Sanctions Due to International Rights Against International Offenses}

The development of each member state requires the cooperation of the organized international community at a level beyond national interests provided that such cooperation is based on principles that guarantee the interests of collective and the result of the conscience of human society if the principles and rules of international law trampled, the violation is considered appropriate that the reaction to them. Sanctions stipulated in international law include civil remedies Impeding international law, moral sanctions, economic sanctions, diplomatic sanctions, political sanctions, public opinion and countermeasures. (Ziaee Bigdeli, 2004)

Now, with the approval of the UN Charter in 1945, which was an objective of common agreement states in the field of international law? It is the highest steps of humanity for peace and human security, public order and the global harvest. To achieve this goal, members of the United Nations primary responsibility for maintaining international peace and security; and in fact the sanction of international law in practice were entrusted to the Security Council. In order to accomplish this task the security council, acting under chapter seventh of the charter in case of confirmed threat to the peace, breach of the peace or act of aggression on the basis of Articles 41 and 42 of the Charter of civilian and military measures prophet to maintain or restore international peace and security.

\section{Criminal Responsibility of Individuals Against Using Chemical Weapons}

The international criminal responsibility if it is a function of international criminal law, violating one of the rules of international law that its violation is considered a crime by the international community, despite legal requirements, committed, was criminal and will be punished. It should be noted here that if they, as individuals and representatives of government agencies, principally the removal of criminal liability in domestic law implemented, undermining the unity of criteria and the documents and the assignment - except in cases of exceptional- international criminal responsibility are also mandatory (Salimi, 1977, p. 26). An important point about international criminal responsibility is that some professors of international law and criminal law that a person who committed a crime outside the country of their origin is international criminals and because of the nationality of the offender, the investigation related to the case, will be required to conduct research abroad; (Busar, 1975: 97) But for criminalizing the act of anti-social and international order, action shall be accompanied by legal sanction. This is the principle arises of "no crime without law does not exist" (principle of legality of crimes) and "there is no punishment without law" (principle of legality of penalties). (Busar, 1996, p. 121).

\subsection{Jurisdiction of the International Criminal on the Responsibility of Individuals}

Governments show effectively respond to the most domestically crime. The national system of domestic law is dealt these crimes. But this history is not considered international crimes and do not have long history. But in war crimes, if a person is able to achieve their goals broad measures would be considered a value. But today we have found that war is not by any means legitimate (Azmayesh, 2009, p. 11) and former; there was no capacity to react to the committed crimes. After World War I, the Treaty of Versailles to combat international crime responded that international criminals should be tried. This is the first spark that objectively it will be remembered for international crimes, but it was forgotten later. Until the outbreak of world war II that took place more severe crimes the international community came to the conclusion that the perpetrators of international crimes should be brought to trial. (Azmayesh, 2009, p. 12) Basically, there are many crimes that do not belongs to a country's internal borders it means the existence of borders, does not prevent the realization of justice in that country, but many crimes, distort the conscience of humanity and the international community have to react by tools of public international law. So after the end of World War II countries attempted to react to crimes that have taken place to establish the international criminal temporarily specifically for this type of crime. The establishment of a permanent international criminal is not respond to these crimes, but also has developed principles and rules of international law that creates obligations for governments. Including the obligation to punish those who commit war crimes, crimes against humanity, or genocide has contributed. (Gripi, 2004, p. 179) Right and duty to punish, firstly, the jurisdiction of the international criminal when states and jurisdiction finds that a member state is unwilling or unable to impose his own authority. Therefore, generally, about the time of the 's jurisdiction is that after joining a state statute, the has the power to impose qualify over committed crimes is located the territory or by nationals of that State. Hence it is not satisfied the need for Member States to apply this . The only exception in this case is envisaged in the Statute, the transitional provisions is Article 124, 
according to this article the government that is the member of this statute for a period of seven years after the entry into force of the Statute, can confirm that the 's jurisdiction over the crimes set forth in (Article 8), who claims to have been committed in the territory or by nationals of that state, cannot accept.

Therefore, all people around the world since the beginning of July 2002, the date of entry into force of the statute of the , regardless of which government it is a member of the statute or not, subject to jurisdiction, are potentially at risk. On the other hand, given that pursuant to article 29 of the Statute of the , crimes within the jurisdiction of this are not subject to time, so every time people commit these crimes are at risk jurisdiction of the .

\subsubsection{Necessity of Establishing the International Criminal}

The twentieth century has been the most violent century in human history. In addition to the global wars of the first half of this century, in the last fifty years, more than 250 clashes occurred around the world as a result of more than 86 million civilians (mostly women and children) died and more than 170 million rights were violated, and their property was destroyed and reputation were attacked. For example, in Cambodia in the seventies just over 2 million people were killed by the Khmer Rouge. Unfortunately committing such crimes in the former Yugoslavia in the Nineties, Rwanda.... systematically planned and indicated that the perpetrators or victims of international crimes are not always given particular nation and over time the range of atrocities and brutality is not affect them. This demonstrates the necessity of establishing the International Criminal . (Norouzi, 2009, p. 18) Another reason that make this necessity more tangible are included: National s negligence and negligence in the prosecution of international criminals, the scope of judicial affairs International of Justice, the inadequacy of specialized international $\mathrm{s}$, jurisdiction when the crime occurred in the future, a fair trial of the International Criminal (Zamani, 2002, pp. 63 -61, Norouzi, 2009, pp. 19-18).

\subsubsection{Personal Qualified of the International Criminal}

In article 11 of the Statute of the is the only competent to investigate offenses committed by persons (real above 18 years). Therefore, the cannot handle criminal responsibility of government.

There are some significant matters are the personal jurisdiction of the:

-If a person is a crime he did not commit the crime, but these have ordered or encouraged to do so is guilty.

-If a person committing a crime of any kind of assistance to crime or attempt to commit the crime of resort is also guilty.

-The official accused persons did not have the jurisdiction. Therefore, any immunity or based on domestic law and international law do not prevents the investigating authorities. (Article 27 of the Statute) should be mentioned issue before the criminal on the Statute of the Yugoslavia and Rwanda as well. In addition, the General Assembly, in resolution 19 (1) of 11 December 46 was approved by consensus principle. It can be stated that the article does not address that privilege prevents in fact, peak limiting state sovereignty since it has been the rule of immunity of State officials from the obvious examples. Military commanders or persons effectively carry out the duties of military commanders for crimes within the's jurisdiction, compliance and in some cases by forces under his effective command and control or under his effective authority and control were committing if he is controlling the forces under his command who have had to apply, is not done (Article 28, paragraph 1, of the Statute).

\subsection{Guarantees of the International Criminal}

The enforcement of international criminal institution as we have the sanction of international law is as penal institution. Because the International Criminal a common agreement about the objective of the government in the area of international law, so the remedies to be granted the concept of international law. First according to the Statute of the examine the sanctions.

\subsubsection{Punishment Prescribed by the International Criminal}

Article 77 of the Statute of the International Criminal as well as personal punishment for committing one of the crimes listed in Article 5 (war crimes, crimes against humanity, genocide) knows the convictions of two of the following:

A) Imprisonment for a specified period not more than thirty years, B) or life imprisonment provided that the person convicted of the crime and the circumstances require it. (Ardebili, 2008, p. 54) C) In addition to the prison sentence, rules regarding the return of proceeds of crime have been predicted. In the second part of the second paragraph of Article 77 of the Statute of the International Criminal decreed that the proceeds, property and assets that are directly or indirectly derived from crime without harm to the rights of third parties, is recorded. (Ardebili, 2008, pp. 55-54) Under article 109 concerning punishable by a fine and confiscation of 
property Member states are obliged to implement the provisions of a fine and confiscation of property or should take measures to preserve the value of goods, property and assets of the has ordered its confiscation orders adoption and transfer them without any harm comes to the rights of third parties. Article 79 mandates that the Assembly of States Parties to support victims and their families will make fund and the may order whatever funds and cash fines and confiscation of property obtained funds to be transferred (Ardebili, 2008, pp. 56-55).

\subsection{Responsibility of States for Acts of Private Parties}

Contrary to international practice under international law when it is assigned to a country the persons or elements under his effective authority, do the action. The behavior or actions of private entities, whether international law cannot be regarded as an act contrary to the Country and he knows the responsibility. However, there may be cases where the actions of private entities territory of a country are early in providing the international responsibility of that country. If the behavior of individuals including the lack of prediction and prevention of fraud or failure to disability or adequacy of controls be necessary from governments. In fact, this exception is only apparent, because in assuming responsibility for the country is caused by the behavior of the pillars itself a commitment to care who is responsible for them have not done, As a result, the negligence of the authorities responsible for his country's commitment to end or compensate for the loss in time that remains to foreigners. So the responsibility for the country caused by applying private individuals, countries have two basic functions: A-duty prediction and prevention: In this phase the competent authorities of each country should be possible to predict events and prevent their occurrence and if necessary, support assign fall of foreigners who threaten. BThe task of pursuing and punishment: If you took action against international law, a country that acts attributed to him is obliged to hunt down and punish the perpetrators with full force from the victims compensation fixes (Ziaee Bigdeli, 1383, pp. 420-419).

\subsubsection{Principle of Universal Jurisdiction}

Prosecuting, punishing perpetrators of war crimes and their accomplices such as partners and long history and dating back more than 60 years since the establishment of the Nuremberg and Tokyo Tribunals State practice criminalizing crime in the preface of the Statute the International Criminal is mentioned as an attempt to extract a century of crimes subject to the statute states as the most serious crimes of concern to the international community. On the other hand, domestic legislation of many countries that produce the main principle (universal jurisdiction) in pursuit of these crimes is very important. This principle is based on the traditional principle of "extradite or prosecute" Therefore, in accordance with the principles of humanitarian law and the Fourth Geneva Convention and the first Additional Protocol, the government is obliged charged with punishment the accused to trial otherwise, he must surrender for trial in other states because the crimes are subject to universal jurisdiction undermined the interests of the whole human community And the government tried to act on behalf of the humanitarian community. (Jahani Ghaemi, 2010, pp. 197-196) The introduction of the Statute of the International Criminal today more than 125 countries, the principle of "universal jurisdiction" in its internal rules included. Among the states exercising universal jurisdiction, Germany is the most active country, as well as the Netherlands, Denmark, Belgium, France and America can be noted in these countries based on impose a large number of perpetrators of crimes against humanity, genocide and war crimes in the former Yugoslavia, Rwanda, Sierra Leone trial were sentenced but Iran has so far approved the rules give rise to the actions of universal jurisdiction is not approved in other countries. (Jahani Ghaemi, 2010, p. 197)

\section{Conclusion}

So far a lot of contracts, especially in the field of weapons of mass destruction disarmament have been concluded, such as the St. Petersburg Declaration of 1868, the final declaration of the conference held in Brussels in 1874 prohibiting the use of poisonous weapons, treaties 1920-1919 Paris, 1925 Geneva Protocol, 1993 Convention on the Prohibition of Chemical Weapons that forbidden development, research, acquisition, stockpiling and use of chemical weapons, and implicated to the need of destroy the whole of this weapons although no criminalization of offensive war crimes are true ,but since, domestic and international laws and national and international direct interaction mutual relationship considering the realities of the rights of international treaties linked the law criminalizing domestic crimes in addition to creating jurisdiction for domestic would also lead to the creation of international norms. The infringement of international law if the government violates the law by establishing the rule of causes of action and liability shall be determined virtual arena several punitive measures that international law, the UN Convention against chemical use and the International Criminal have been approved Including; extradition and imprisonment for individuals, legal entities fined for financial administrative penalties apply for natural and legal persons and parallel civil liability committed in the restoration of the former state and the impossibility of restitution, compensation is due to the violation of the laws in force. 
But some remedies that have no executive power envisaged in the UN Charter, because the UN Security Council to impose a sanction only in limited circumstances and often this council have the authority to veto the council's five permanent members, it is down in the International Criminal, which the Security Council's decision followed the failure to guarantee effective implementation of the decisions.

On the other hand, the center of power such as (America, Britain and France) have their own human rights problems formulate and adopt international instruments mentioned in selective positions in the principles and norms of international law makes virtually the prosecution of war criminals (deputies and stewards) adhered neglected and treating international and deal with violators of human rights and administrative justice, implementation of international principles and norms placed in this area. As Iraq's eight-year war against Iran in violation of the 1925 Geneva Protocol was met with silence from the international community and lack of political independence, human rights organizations and their work in the interests of world powers is one of the main obstacles to the implementation of international instruments in the field of human rights so above discussion, main hypothesis which states: "The impact of global powers on international issues, lack of law and lack of government guarantees good performances are the most important challenges." proven.

\section{References}

Afrasyabi, M. E. (1977). General Criminal Law, 2, 1st Ed., Tehran: University.

Ardabil, M. A. (2008). International criminal law, Selection of Articles 1, fourth edition, Tehran: Mizan.

Azmayesh, A. (2009). Lessons pleadings international criminal law, international law graduate, Allameh Tabatabaei University.

Bvsar, A. (1996). International crime, first edition, translated by Negar rakhshani, Tehran: Ganje Danesh.

Grapefruit, E. (2004). The International Criminal and international law, translation Beygzadeh, I. Theology and Law Journal, XIII.

Jahani, G. F. (2010). How to plan fights against Western companies selling chemicals to Iraq, First edition, Proceedings of the International Seminar on the consequences of use of chemical weapons against the Islamic Republic of Iran, Tehran, Shahed Publication.

King, M. (2005). Mahatma Gandhi and Martin Luterknig, the power of non-violent struggle, First edition, translation Naghshe Tabriz, Sh, Tehran: Nashre Ney.

Mir Mohammad Sadeghi, H. (1977). International Criminal Law, first edition, Proceedings, Tehran: Mizan.

Mir, A., \& Syed, B. (2003). Public International Law, Volume II, Tehran: Nashre Mizan.

Norouzi, M. (2009). Guarantees the implementation of the decisions of the International Criminal , thesis, Allameh Tabatabaei University, Tehran.

Rahgosh, A. H. (2007). Analysis of criminal responsibility of governments, specialized scientific journal Bar Association Fars region, Third Volume, Issue 6. Retrieved from http://www.daneshju.ir

Salimi, S. (1977). Criminal phenomenon of international law and the rights of the Iranian penal criminal responsibility, Khayyam.

Shebs, William. (2005). Introduction to the International Criminal, printing, translation and Dr.Mir Abbasi, S.G. Alhavy, H., Tehran: Jangal.

Yadegarfar, M. (1997). Inspection systems of weapons of mass destruction. Defence Science Journal, 25.

Zamani, S. G. (2002). The establishment of the International Criminal : Fears and Hopes, Journal of Law, No. 2

Ziaee Bigdeli, M. R. (2004). Public International Law, the nineteenth edition, Tehran: Ganje Danesh.

\section{Copyrights}

Copyright for this article is retained by the author(s), with first publication rights granted to the journal.

This is an open-access article distributed under the terms and conditions of the Creative Commons Attribution license (http://creativecommons.org/licenses/by/4.0/). 